\title{
Metformin-associated Lactic Acidosis Requiring Intensive Care in a Regional Hospital in Hong Kong and Predictive Factors for Mortality
}

Metformin-associated lactic acidosis (MALA) has estimated the incidence of 3-9/100,000 patient-years ${ }^{[1]}$ and mortality rate ranging from $9.1 \%$ to $61 \%$ with inconsistent prognostic factors $^{[1-3]}$ [Table 1].

Patients admitted to Intensive Care Unit (ICU) of Queen Elizabeth Hospital in Hong Kong between January 2011 and December 2015 were included in the retrospective study if they met the following criteria: (1) metformin as usual treatment or overdose; (2) peak lactate $>5 \mathrm{mmol} / \mathrm{L}$; (3) $\mathrm{pH}<7.35$ and bicarbonate $<22 \mathrm{mmol} / \mathrm{L}$. Patients were excluded if they were admitted for (1) postcardiac arrest or (2) postoperative care or (3) conditions other than MALA in which investigators identify as the main cause of lactic acidosis. This study was performed in compliance with ethical standard of the Helsinki declaration and approved by the research ethics committee.

Eighty-four patients with elevated lactate level had taken metformin as usual medication or overdose. Twenty-five patients were excluded due to postcardiac arrest $(n=4)$, postoperative care $(n=15)$, extracorporeal membrane oxygenation therapy $(n=4)$, nonacidemia $(n=1)$, and massive ST-elevation myocardial infarction $(n=1)$.

The baseline characteristics of the eligible patients were summarized in Table 2.

Compared with the 54 survivors, the 5 nonsurvivors had higher Acute Physiology and Chronic Health Evaluation IV (APACHE IV) scores $(P=0.005)$, APACHE IV predicted

\begin{tabular}{|c|c|c|c|c|c|c|c|}
\hline First author & Country & Period & Mortality (\%) & $\begin{array}{l}\text { Precipitating } \\
\text { factors (\%) }\end{array}$ & $\begin{array}{l}\text { Number of } \\
\text { patients }\end{array}$ & $\begin{array}{l}\text { Metformin } \\
\text { level }\end{array}$ & Factors for mortality identified \\
\hline Spiller & US & $1996-2000$ & 13 & N/A & 68 & N/A & N/A \\
\hline Renda & Italy & 2001-2011 & 25 & 89 & 59 & N/A & Low $\mathrm{pH}$ and absence of ARF \\
\hline Lalau & France & NA & 45 & 100 & 49 & Any level & Low metformin level \\
\hline Li Cavoli & Italy & 2008-2009 & 10 & 100 & 47 & N/A & N/A \\
\hline Misbin & US & 1995-1996 & 42 & 91 & 47 & N/A & N/A \\
\hline Seidowsky & France & $1998-2007$ & 33 & 69 & 42 & $>2 \mathrm{mg} / \mathrm{L}$ & $\begin{array}{l}\text { LODS age, arterial } \mathrm{pH} \text {, arterial } \\
\text { lactate level, PT activity, mechanical } \\
\text { ventilation and need for vasoactive } \\
\text { support. Also intentional overdose } \\
\text { good prognosis }\end{array}$ \\
\hline Peters & France & $2002-2007$ & 30 & 100 & 30 & $\mathrm{~N} / \mathrm{A}$ & Reason for admission and initial PT \\
\hline Vishwanath Biradar & Australia & $30 \%$ & & 65 & 17 & N/A & $\begin{array}{l}\text { APACHE III score, arterial } \mathrm{pH} \text { on } \\
\text { admission and male sex }\end{array}$ \\
\hline Farshad Kajbaf & France & $1995-2010$ & 47 & 95 & 58 & Any level & $\begin{array}{l}\text { Sepsis, multidrug overdoses and the } \\
\text { presence of at least two triggering } \\
\text { factors for lactic acidosis }\end{array}$ \\
\hline Vecchio S & Italy & $2007-2011$ & 26 & 100 & 66 & $>4 \mathrm{mg}$ & $\begin{array}{l}\text { Just exclude lactate and metformin } \\
\text { level as factors for mortality }\end{array}$ \\
\hline Yeung CW & HK & 2006-2010 & 30 & 96 & 23 & Any level & Shock and high plasma lactate levels \\
\hline Duong JK & Australia & 2008-2011 & 20 & 93 & 15 & N/A & N/A \\
\hline Our study & HK & 2011-2015 & 8.5 & 93.2 & 59 & N/A & $\begin{array}{l}\text { APACHE IV score, APACHE } \\
\text { IV predicted mortality risk, } \\
\text { temperature, heart rate and } \mathrm{PaCO}_{2} \text {, } \\
\text { lower first } 24 \mathrm{~h} \text { urine volume } \\
\text { and serum albumin; mechanical } \\
\text { ventilation, sepsis, higher median } \\
\text { maximum dosage of noradrenaline } \\
\text { infusion, longer median time from } \\
\text { hospital admission to RRT }\end{array}$ \\
\hline
\end{tabular}

N/A: Not available; APACHE: Acute Physiology and Chronic Health Evaluation; RRT: Renal replacement therapy; LODS: Logistic organ dysfunction system; ARF: Acute renal failure; PT: Prothrombin time 
mortality risk $(P=0.003)$, temperature $(P=0.032)$, heart rate $(P=0.035)$, and $\mathrm{PaCO}_{2}(P=0.002)$; and lower first 24 -h urine volume $(P=0.013)$ and serum albumin $(P=0.012)$. They were more likely to be on mechanical ventilation $(P=0.014)$ and suffer from sepsis $(P=0.001)$. They had higher maximum dosages of noradrenaline infusion $(P=0.009)$ and longer

Table 2: Patient baseline characteristics, precipitating factors, and outcome

\begin{tabular}{|c|c|}
\hline Characteristics & MALA patients $(n=59)$ \\
\hline Age & $68.4(11.7)$ \\
\hline BMI $\left(\mathrm{kg} / \mathrm{m}^{2}\right)$ & $20.8(2.9)$ \\
\hline Baseline creatinine $(\mu \mathrm{mol} / \mathrm{L})$ & $103.1(31.1) / 1.16(0.35)$ \\
\hline eGFR (ml/min/1.73 m²) & $65.5(28.8)$ \\
\hline Metformin dosage & $2000 \mathrm{mg}(1000-2125)$ \\
\hline Heart rate & $94.9(28)$ \\
\hline Respiratory rate & $22.2(5.3)$ \\
\hline Mean arterial blood pressure $(\mathrm{mmHg})$ & $65.3(16.1)$ \\
\hline Maximum noradrenaline $(\mathrm{mcg} / \mathrm{kg} / \mathrm{min})^{¥}$ & $0.61(0.11-1.73)$ \\
\hline Noradrenaline and adrenaline & $12(20.3)$ \\
\hline First $24 \mathrm{~h}$ urine in ICU $(\mathrm{ml})^{*}$ & $479(89-1398)$ \\
\hline \multicolumn{2}{|l|}{ Blood tests upon admission } \\
\hline Potassium (mmol/L) & $6.1(1.24)$ \\
\hline Urea $(\mathrm{mmol} / \mathrm{L})$ & $25.3(8.9)$ \\
\hline Creatinine $(\mu \mathrm{mol} / \mathrm{L})$ & $546.8(294)$ \\
\hline $\mathrm{pH}$ & $6.98(0.23)$ \\
\hline Bicarbonate $(\mathrm{mmol} / \mathrm{L})$ & $6.5(4.9)$ \\
\hline Peak lactate $(\mathrm{mmol} / \mathrm{L})$ & $14.5(6.2)$ \\
\hline \multicolumn{2}{|l|}{ Mechanical ventilation/RRT } \\
\hline Mechanical ventilation* (\%) & $28(47.5)$ \\
\hline PF ratio ${ }^{*}$ & $359(208-489)$ \\
\hline \multicolumn{2}{|l|}{ Initial RRT* (\%) } \\
\hline $\mathrm{CVVH}$ & $44(74.6)$ \\
\hline CVVHDF & $11(18.6)$ \\
\hline No & $4(6.8)$ \\
\hline Time from admission to RRT $(\mathrm{min})^{*}$ & $409(160-860)$ \\
\hline Time from RRT to free from RRT (days) ${ }^{*}$ & $1.83(0.82-3.47)$ \\
\hline \multicolumn{2}{|l|}{ Composite severity score } \\
\hline APACHE IV score & $112.0(28.1)$ \\
\hline APACHE IV risk & $0.46(0.27)$ \\
\hline SOFA score ${ }^{*}$ & $9(7-11)$ \\
\hline \multicolumn{2}{|l|}{ Outcome } \\
\hline ICU mortality* (\%) & $5(8.4)$ \\
\hline 30 days mortality* (\%) & $7(11.9)$ \\
\hline 1 year mortality* $(\%)$ & $12(20.3)$ \\
\hline 1 year creatinine $(\mu \mathrm{mol} / \mathrm{L})$ & $153.8(113.6)$ \\
\hline Metformin usage on 1 year follow-up* & 11 \\
\hline \multicolumn{2}{|c|}{$\begin{array}{l}\text { Results shown as mean } \pm \text { SD unless otherwise specified. * } n(\%) ;{ }^{*} \text { Median } \\
\text { (inter-quartile range). BMI: Body mass index; eGFR: Estimated } \\
\text { glomerular filtration rate by modified diet in renal disease study equation; } \\
\text { RRT: Renal replacement therapy; APACHE: Acute Physiology and } \\
\text { Chronic Health Evaluation; SOFA: Sequential organ failure assessment; } \\
\text { ICU: Intensive Care Unit; MALA: Metformin-associated lactic acidosis; } \\
\text { CVVH: Continuous veno-venous hemofiltration; CVVHDF: Continuous } \\
\text { veno-venous hemodiafiltration; PF: } \mathrm{PaO}_{2} \text { to } \mathrm{FiO}_{2} \text { ratio; SD: Standard } \\
\text { deviation }\end{array}$} \\
\hline
\end{tabular}

median time from hospital admission to commencement of renal replacement therapy (RRT).

The receiver operating characteristics curve for the time from admission to RRT with the outcome of mortality had an area under curve of $0.776(P=0.043)$. Sensitivity and specificity would both be $80 \%$ if the cutoff was set at $765.5 \mathrm{~min}$ from admission to RRT [Figure 1].

When comparing patients with other precipitating factors, patients with sepsis were found to have higher heart rates $(P=0.016), \mathrm{PaCO}_{2}$ levels $(P=0.017)$, APACHE IV risk $(P=0.02)$, sequential organ failure assessment score $(P=0.001)$, and maximum nor-adrenaline infusion dosages $(P=0.001)$, with higher rates of mechanical ventilation $(P=0.013)$ and ICU mortality $(P=0.001)$.

Patients with intentional self-inflicted overdose had higher $\mathrm{pH}(P=0.009)$ and bicarbonate $(P<0.001)$; and lower serum creatinine level $(P<0.001)$, APACHE IV predicted mortality risk $(P=0.02)$, maximum noradrenaline infusion dosages $(P=0.043)$, and rate of RRT $(P<0.001)$. None of the patients died in the ICU but there is no significant difference in ICU mortality.

Septic patients and patients with higher serum creatinine level had a longer duration of RRT dependence [Figures 2 and $3 ; P=0.026$ and 0.005 , respectively].

RRT would be theoretically beneficial in MALA by the elimination of metformin and lactate, correction of acidosis and electrolyte abnormalities and as a support for impaired kidney function. Our study is the first study to demonstrate a longer time from hospital admission to RRT in nonsurvivors, suggesting a beneficial effect of early RRT. The benefits of early RRT in critically ill patients have been debated. In 2016, there were two randomized controlled trials published on

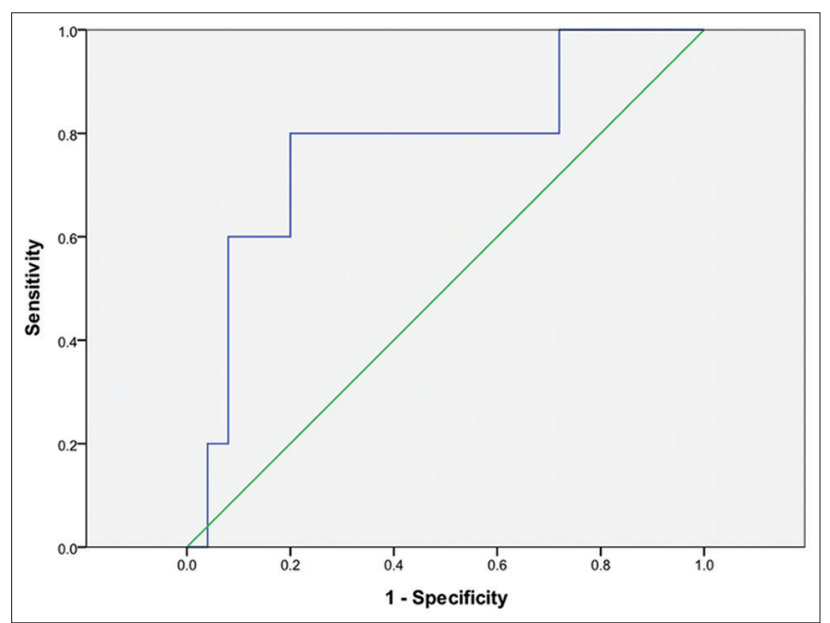

Figure 1: Receiver operating characteristics curve of time from admission to renal replacement therapy commencement for predicting mortality. Area under curve $=0.776\left(P=0.043^{\star}\right)$ 


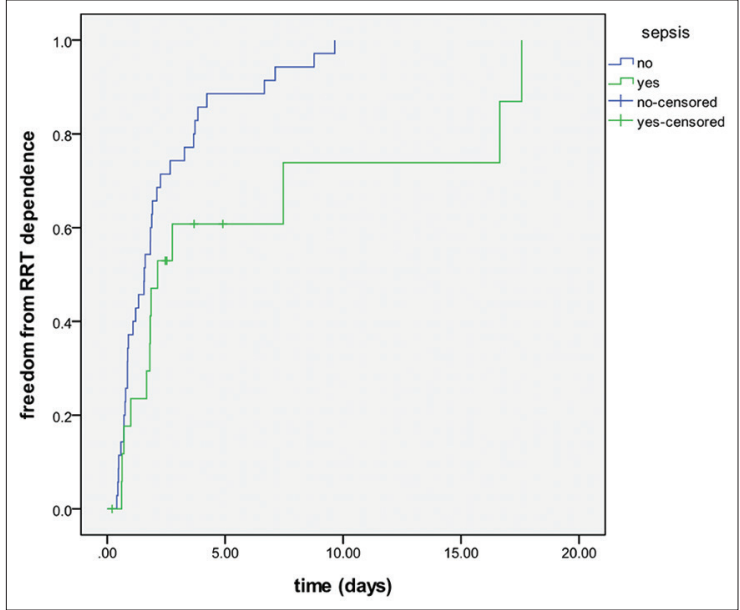

Figure 2: Time to freedom from renal replacement therapy dependence in septic and nonseptic metformin-associated lactic acidosis patients $(P=0.026)$

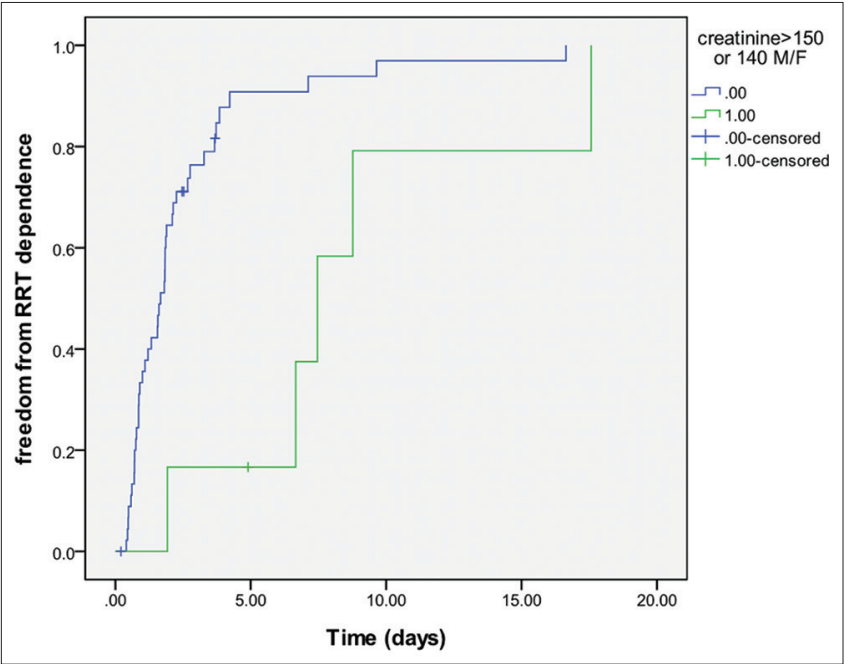

Figure 3: Time to freedom from renal replacement therapy dependence in patients with or without serum creatinine $>150 \mu \mathrm{mol} / \mathrm{L}$ in male or $140 \mu \mathrm{mol} / \mathrm{L}$ in female $(P=0.005)$

early versus late RRT in critically ill patients with different results. $^{[4,5]}$

\section{Financial support and sponsorship}

Nil.

\section{Conflicts of interest}

There are no conflicts of interest.

\section{Chung-Tat Lun, Henry Jeffrey Yuen ${ }^{1}$, George Ng$^{1}$, Sheung-On So,} Anne Leung ${ }^{1}$, Kang-Yiu Lai

Department of Medicine and ICU, Alice Ho Miu Ling Nethersole Hospital, Tai Po, ${ }^{1}$ Department of Intensive Care Unit, Queen Elizabeth Hospital, Kowloon, Hong Kong

Address for correspondence: Dr. Chung-Tat Lun Intensive Care Unit, Alice Ho Miu Ling Nethersole Hosptial, 10 Cheun on Road, Tai Po, Hong Kong. E-mail: Ict134@ha.org.hk

\section{References}

1. Kajbaf F, Lalau JD. The prognostic value of blood $\mathrm{pH}$ and lactate and metformin concentrations in severe metformin-associated lactic acidosis. BMC Pharmacol Toxicol 2013;14:22.

2. Kajbaf F, Lalau JD. Mortality rate in so-called "metformin-associated lactic acidosis": A review of the data since the 1960s. Pharmacoepidemiol Drug Saf 2014;23:1123-7.

3. Seidowsky A, Nseir S, Houdret N, Fourrier F. Metformin-associated lactic acidosis: A prognostic and therapeutic study. Crit Care Med 2009;37:2191-6.

4. Gaudry S, Hajage D, Schortgen F, Martin-Lefevre L, Pons B, Boulet E, et al. Initiation strategies for renal-replacement therapy in the Intensive Care Unit. N Engl J Med 2016;375:122-33.

5. Zarbock A, Kellum JA, Schmidt C, Van Aken H, Wempe C, Pavenstädt H, et al. Effect of early vs. delayed initiation of renal replacement therapy on mortality in critically ill patients with acute kidney injury: The ELAIN randomized clinical trial. JAMA 2016;315:2190-9.

This is an open access article distributed under the terms of the Creative Common Attribution-NonCommercial-ShareAlike 3.0 License, which allows others to remix, tweak, and build upon the work non-commercially, as long as the author is credited and the new creations are licensed under the identical terms.

\begin{tabular}{|l|l|}
\hline \multicolumn{3}{|c|}{ Access this article online } \\
\hline Quick Response Code: & Website: \\
& www.ijccm.org \\
\hline
\end{tabular}

How to cite this article: Lun CT, Yuen HJ, Ng G, So SO, Leung A, Lai KY. Metformin-associated lactic acidosis requiring intensive care in a regional hospital in Hong Kong and predictive factors for mortality. Indian J Crit Care Med 2017;21:875-7.

C 2017 Indian Journal of Critical Care Medicine | Published by Wolters Kluwer - Medknow 